\title{
Preaching, the city, and the saints: an analysis of the civic-liturgical context of the Venit in civitatem suam sermons (1304) by Giordano da Pisa (c. 1260-1311)
}

\author{
A Pregação, A Cidade E Os Santos: Uma Análise \\ Do Contexto Cívico-Litúrgico Dos Sermões Venit In \\ Civitatem Suam (1304) De Giordano De Pisa (C. 1260-1311)
}

Aléssio Alonso Alves*

\section{Resumo}

Este artigo explora o contexto cívico-litúrgico de três sermões do frade Pregador Giordano de Pisa, pronunciados em uma mesma semana de 1304 em Florença (dois no domingo e um na quinta-feira), todos a partir do versículo de Mateus 9, 1 (Venit in civitatem suam). Com base em considerações a respeito da escolha do versículo bíblico, bem como do exame de outros documentos da Ordem Dominicana e dois livros litúrgicos da catedral florentina, argumenta-se que o frade escolheu deliberadamente não seguir os costumes litúrgicos de composição sermonística nessas pregações. Conclui-se, assim, que isso foi feito com o objetivo de estabelecer uma reflexão sobre a cidade (o ambiente humano por excelência tanto na Terra quanto no Céu), tendo em vista a festa cívico-religiosa de Santa Reparata, padroeira de Florença, que ocorreria na quinta-feira. Palavras-chave: Giordano de Pisa; pregação; religião cívica.

\section{Abstract}

This article explores the civic-liturgical context of three sermons by the friar Preacher Giordano da Pisa, delivered during a same week of 1304 in Florence (two on Sunday and one on Thursday), all of them from the verse of Matthew 9, 1 (Venit in civitatem suam). Based on considerations regarding the choice of the biblical verse, as well as the examination of other documents of the Dominican Order and two liturgical books of the Florentine cathedral, I argue that the friar deliberately chose not to follow the liturgical customs of sermon composition in these preachings. Thus, it is concluded that this procedure was made to establish a reflection on the city (the quintessential human environment, both on Earth and in Heaven) in view of the civic-religious feast of Saint Reparata, Florence's patroness saint, which took place on Thursday.

Keywords: Giordano da Pisa; preaching; civic religion.

\footnotetext{
* Universidade Federal de Minas Gerais (UFMG), Belo Horizonte, MG, Brasil. alessioaalves@gmail. com. < https://orcid.org/0000-0001-9634-792X>
} 
On a Thursday morning, 8 October 1304, a crowd gathered in the square in front of Florence's Cathedral, Santa Reparata, also known as Liperata. It was the feast day of the saint who named the church, the city's patroness. Due to the presence of all the city clergy and probably the large number of people present, the second preaching they were waiting for was performed outside the church (Giordano da Pisa, 1831, p. 88; Toker, 2009, p. 278-279)'1't the building, with modest proportions and already in process of being demolished for the construction of a new cathedral, would not hold such a large number of spectators (Thompson, 2005, p. 30-123; Toker, 2009, p. 3) ${ }^{2}$.The sermon had been charged to the lector and Preacher General of the Dominican Order, friar Giordano da Pisa (c. 1260-1311) (Delcorno, 1975, p. 3-28; Delcorno, 2001; Corbari, 2008, p. 49-58) ${ }^{3}$. Early in his speech, most likely after announcing the thema $a^{4}$ of Matthew 9, 1 (Venit in civitatem suam), he cried out to the Florentines:

About all this word I preached throughout this week and now I will preach this morning in honour of this virgin and martyr Saint Reparata. Said the Wise that it is natural and proper for man to be in the city, and the reason is that, as that great Wise said, man is an assemblable and social animal, and does not know how to exist without companion. (Giordano da Pisa, 1831, p. 88)

Shortly afterwards, once again Giordano referred to the sermons already preached that week, all enclosed in the city theme: "[...] As I said the other day, our Lord Jesus Christ had three cities [...] the other day I said about the features of the city and why it is called city [...]" (Giordano da Pisa, 1831, p. 89-90).

In order to have a fuller understanding of all these preachings and of the context of the civic-theological reflection undertaken by the preacher, the friar's activities on the previous Sunday, 4 October, feast day of Saint Francis of Assisi (1181-1226), must be reconstructed so that his choices may be understood. This is necessary due to the fact that this Thursday sermon is closely linked by thema to the two others that were recorded on that first day of the week. The importance of examining Giordano's procedures, as well as clarifying the context of these sermons and demonstrating the civic-liturgical importance of the feast of Saint Reparata, lies in the fact that these three sermons were taken by historians as some of the most expressive of his preaching in civic-political terms. Such appreciation occurs because in them Giordano openly addressed the city theme by relating the earthly and heavenly cities and establishing the latter as a model for the former - besides making direct references to Aristotle's philosophical- 
political thought regarding the reason and origin of human society according to the beginning of Politics (Hub, 2012, p. 74-75; Iannella, 1999, p. 43-49; 2005, passim; Meier, 1994, p. 47-54; 2006, p. 16-21; Miatello, 2017). However, although they highlight these features very well and demonstrate a close relationship between preaching/sermon and politics in early fourteenth-century Florence, no historiographical analysis has so far focused deeply on the characteristics that are intended to be scrutinized in this article. The main hypothesis of this article is that the preacher intentionally chose the verse of Matthew 9, 1 in view of Saint Reparata's civic-religious feast celebrated on Thursday: by featuring the word civitas, the thema gave the preacher a proper opportunity to preach about both earthly and heavenly cities and to reflect on the relationship between them and the saints. The examination that will be undertaken, although not contradicting the conclusions of these studies, is in line with their terms and reinforces them as it further emphasises the civic-political character of the Giordanian preaching.

The reportationes (transcription of the preacher's speech) of the three Venit in civitatem suam sermons are found in two fourteenth-century manuscripts of Italian provenance: the ms. II IV 145 of the Biblioteca Nazionale Centrale (formerly the Libreria Magliabechiana), Florence; and the ms. Palatino 23 of the Biblioteca Universitaria, Parma. In both of them, the sermons come in sequence. Based on the first manuscript, they were published in 1831, along with 66 others, by Domenico Moreni in two volumes (Giordano da Pisa, 1831, p. 5-6; Delcorno, 1975, p. IX, 299). This edition, still the only one published to date, was employed in this research.

\section{Preached friar Giordano, 4 OCTOBER 1304, SUNDAY morning, Saint Francis' day in Santa Maria novella}

Despite the feast of the Minorite saint, while preaching in the convent church of the Friars Preachers in Florence, Giordano delivered his sermon from the Gospel reading of the Sunday Mass (Matthew 9, 1), therefore, following his Order's proprium de tempore lectionary. This verse is found in the pericope of the Nineteenth Sunday after Trinity Sunday (verses 1-8) beginning with the story of how Jesus took a boat and came to his city, returning to Capernaum (Ordo Praedicatorum, 1484, passim).

As regards the feast of Saint Francis, it would be more appropriate and convenient for Giordano to have chosen the gospel reading designated for the 
saint's feast: according to the Dominican liturgical calendar, the date of 4 October should be dedicated to his celebration. As the Order's Ordinarium and Missale $^{5}$ establishes, for his Mass was scheduled the gospel reading of Luke 11, 33 and the epistolary reading of Tobit 23, 26 (Bonniwell, 1945, p. 109; Ordo Praedicatorum, 1484, passim). According to the sermon composition treatise Libellus artis predicatorie (1290) of the also Dominican Jacobus da Fusignano (?-1333), "in sermons on feast days the thema may be taken from any place in the Scripture, but from the one that best suits the solemnity" (Jacobus da Fusignano, 2013, p. 24). In this sense, while Giordano was not obliged by any formal rule to choose the thema from the liturgical readings in honour of the saint, surely the passages that most suited the solemnity were those officially established by the liturgy.

And even though the feast appears on the Dominican Order calendar as simplex ${ }^{6}$ - a second-level celebration on a five-degree scale ${ }^{7}$ - its readings should be preferred to those of an ordinary Sunday Mass. As the historian Anne-Élisabeth Urfels-Capot has observed, according to the rules of the Order's Ordinarium, in the case of concurrence of solemnities the difference between them establishes the total or partial supremacy of a feast of superior hierarchy over an inferior one (Urfels-Capot, 2007, n. 26, p. 28,). In it, the heading 252 which opens the section "On the feasts in common" states: "On any day a simple or greater feast occurs, may it be celebrated therein"; there are exceptions predicted by the text, but none of them contemplate the Nineteenth Sunday after Trinity Sunday (Ordo Praedicatorum, 1921, p. 65). Given this information, it is clear that there were no official or theoretical excuses that would support Giordano's choice of the Gospel passage of Matthew 9, 1 to celebrate the day of Saint Francis of Assisi. This suggests a deliberate choice of the friar. Moreover, as the Italian philologist and literary historian Carlo Delcorno has pointed out, Giordano did so only in one more occasion: on the feast day of Saint Apollinaris (July 23), when the pericope of Luke 22, 24-30 was neglected by the reading of Luke 5, 10, a verse within the pericope of the preceding Sunday (verses 1-11), the Fifth Sunday after Trinity Sunday (Delcorno, 1975, p. 121-400). This indicates that this practice was not in Giordano's custom, which makes the case here under consideration an exception.

The attitude of adopting a thema according to the preceding Sunday liturgy and ignoring the specific reading for the feast of a saint was reprimanded some 35 years later by Friar Preacher Thomas Waleys (?-1350) in his treatise De modo componendi sermonis cum documentis (Delcorno, 1975, p. 121). According to the English friar, 
When it is preached on the saints, the thema is taken from the gospel or the epistle read that day or some other part of the Scripture. However, recently preachers have innovated in some new custom in which from the Sunday immediately preceding the feast of the saint, whatever the Sunday, the thema is assumed to be preached about on the feast of the saint that takes place throughout the week. And thus they are bound to this custom - if one should say custom - that, when finding the gospel of that Sunday in agreement or not with the feast of the saint, yet they still take that thema. But I see no rational reason for this custom. However, this I know: that they often take their thema with struggle and violence and they strive to adapt it to the saint and, as not succeeding in doing so decently and in a proper manner, that thema, which should be the whole foundation of the sermon, deforms it entirely, no matter how well preached. Thus, it seems to me that the custom of others, which is older and shared, is better, that is, by which the saint's thema is taken from the Holy Scripture, from anywhere in it, so that it may be more in agreement with the feast and the preacher most grateful in doing so. This way is more rational because it is easier and more useful, and less suspicious of vanity and harmful curiosity. (Thomae Waleys, 1936, p. 342-343)

This reprimand can be simultaneously interpreted in two ways: 1) as evidence that the practice was indeed recurrent for at least 35 years, otherwise there would be no reason for censorship; 2) that, despite this, there was an effort on the part of the Order of Friars Preachers to discourage it. And both things somehow happened to Giordano himself as pointed out by Delcorno:

[...] friar Giordano, from 1305 onwards, abandoned the boldest forms of preaching, turning himself to simpler and more uniform models. And this is identically repeated in the narrower scope of the choice of the sermons' themes: to the fondness for innovation and invention, requested by the public's vivid sense, follows the tendency to accept the proposals of the Dominican liturgy. It is significant that the thematic verses of the feasts of Saint Andrew, Saint Thomas of Canterbury, and Saint Silvester, freely chosen in the years preceding 1305, are then taken only from the Dominican Ordinary. (Delcorno, 1975, p. 120-121)

In this sense, therefore, there is nothing more in agreement with a saint's celebration than the evangelical reading already designated by liturgy for his feast - this being Thomas Waleys' first prescription for preaching in those days and the basis for Giordano's themata choices from 1305 onwards. Nevertheless, with sophistication and without "violence" against the thema, Giordano effectively honoured Saint Francis (Delcorno, 1975, p. 121, n. 26), praising him 
for his effort to return to the celestial city and, by his example, showing the way to it.

However, Giordano's deviation from the liturgical determination when choosing the thema for a sermon in honour of Saint Francis was not entirely without precedent. In his collection of model sermons entitled Sermones de omnibus sanctis (1267-1286), the Italian Dominican friar Iacopo de Varazze (1228-1298) proposed from three to nine sermons for the saints feast days and liturgical celebrations as foreseen in the Order's calendar. Regarding the four sermons dedicated to the saint of Assisi, the friar did not use the pericope prescribed by the liturgy, but employed the passages of Revelations 22, 11; Revelations 7, 2; Galatians 6, 17; and Matthew 11, 28 (Jacques de Voragine, 1573, p. 383-388). The reading of Galatians ("I bear in my body the marks of the Lord Jesus") was later made official as the epistolary reading for the feast day of Saint Francis, and remains so to the present - most likely because Francis received Christ's stigmata on 17 September 1224. This may indicate that preachers preferred it by the second half of the thirteenth century, so that with constant use it was eventually normalized. In this case, however, Giordano would also not have been guided by what was common practice in his day.

Having then opted for the prescribed reading for the Nineteenth Sunday after Trinity Sunday, it should also be noted that Giordano could have delivered his discourses from the first eight verses of Matthew 9. However, he chose to address only the first. In this regard, a comparison with Iacopo of Varazze's production is relevant. In his Sermones de omnibus evangeliis dominicalibus (1267-1286), for this Sunday the friar divided the first two verses of chapter nine into the three proposed sermons. In the first, he started from the sentence "And getting into the boat, he went to the other side, and came to his city", which corresponds to the whole first verse and a segment of the second. In its turn, the second sermon was based on the passage "[...] they brought him a paralytic, lying on a bed. And Jesus seeing their faith [...]", the continuation of the second verse. And finally, in the third text he used the phrase "[...] Jesus said to the paralytic", still from the second verse (Jacques de Voragine, 1572, p. 340-347). This shows that Giordano could not only have chosen one of the officially determined liturgical readings to honour the Minorite saint, but also, as regards the temporal lectionary as did Iacopo, have preached from the other usual verses that were read on this Sunday. However, he chose to remain in all preachings (both Sunday and Thursday) only in the first one. This seems to have been a deliberate choice and shows some difference of intent as regards the two preachers. It is well-known that Iacopo's sermons were written to serve 
as models, and may therefore have been composed to cover a wide variety of subjects, addressing the whole evangelical pericope more fully. But what, then, was the reason for Giordano da Pisa's choice? Is it possible to conjecture any explanation for his preference? These questions take on even greater dimensions when one realizes that, according to Delcorno, the preacher generally adopted the readings indicated by the Dominican liturgy as thema, remaining faithful to the original occasion of the sermon, and rarely neglected the precise rules of sermon composition stipulated by the treatisers (Delcorno, 1975, p. 117-119; p. 360).

As will be argued further ahead, the preacher chose the verse of Matthew 9, 1 in view of Saint Reparata's civic-liturgical feast that was to be celebrated on the forthcoming Thursday, thus creating a train of thought shared by all his sermons of the week. And did so consciously since, by featuring the word civitas, the verse offered an adequate opportunity to speak of the city as the quintessential human environment, both on Earth and in Heaven. In the sermon in honour of Saint Francis, based on Aristotle's philosophical-political theory, Giordano argued that the holy city of eternal life is, by nature, the original place of man (which, before being composed of flesh, is fundamentally soul); the place to which all humans should return as did the saint of Assisi in imitating Christ, who took a boat and came to his city. Saint Francis, therefore, would be the perfect heavenly citizen, a model to be observed by the Florentines: "our city, the saints say, is that blessed city of eternal life, where those blessed citizens are, that is the natural place of the soul [...] about the blessed mister Saint Francis it is shown how he was zealous and eager to return to that city" (Giordano da Pisa, 1831, p. 65-66).

\section{Preached FRIAR GIORDANO THAT SAME DAY IN SANTA LIPERATA IN THE AFTERNOON}

Regarding Giordano' Sunday preaching (October 4), there are two sermons whose annotation were made: the one in honour of Saint Francis and another one delivered in the afternoon, in the cathedral. However, there is the possibility that there was a third one that was not recorded or that part of this second sermon was not registered. In the first Sunday sermon Giordano suggested that he would deliver three sermons or that his speech throughout the day would occur from three points, according to thema's words: 1) Venit; 2) in civitatem; 3 ) suam. The last part (perhaps a complete third sermon), how- 
ever, was not recorded. At the end of the reportatio of the second Sunday preaching, the reportator wrote: "And also about the other part, that is, how that [heavenly city] is our natural place, in what is said by suam - and this is a great treatise - let it be". The loss of part of his Sunday preaching can also be attested by the comparison between the topics announced in the first Sunday sermon and the contents recorded. Both Sunday sermons effectively correspond to the themes announced by the word venit and the expression in civitatem. However, the Thursday sermon (in honour of Saint Reparata and on the reasons why the saints are lords of earthly cities, of the city of eternal life, and of those that adopt them as patrons), categorically does not correspond to the subject announced by the word suam (the creatures' natural appetite and desire to return to their natural place) (Giordano da Pisa, 1831, p. 66-67, 88100 ). This should be very clear when analysing these plural preachings as to their content and specially as a set of sermons connected by the same thema.

As to the sermon preached this Sunday afternoon in the cathedral, Giordano also did not proceed according to the liturgy of the church in which he spoke. Although there is no document featuring its liturgical calendar as current in the thirteenth and fourteenth centuries, Marica Tacconi and Franklin Toker have rebuilt it by means of the Archiepiscopate Antiphonary (1150) and two ordinaria, the Ritus in ecclesia servandi (1173-1205) and the Mores et consuetudines canonice florentini (1231), publishing it in modern editions (Tacconi, 2005, p. 54-56; Toker, 2009, p. 57-65). According to it, on 4 October the feast of the saint of Assisi should be celebrated (Tacconi, 2005, p. 59; Toker, 2009, p. 62, 247). As shown by the transcription of the Ritus published by Toker (2009, p. 157-264), the reference to Saint Francis and his feast was later added to the work in a side note since it predates the saint's life. It reads: "On the feast of Saint Francis, confessor and non-priest, nine readings are made". This means that on the day of the saint's feast one should observe the heading "On the confessor non-pontifical or -priest", which states: “[...] we say [...] In the office of the Mass [...] the Epistle Beatus vir qui inventus or Justum deduxit; the gospel Vigilate [Matthew 24, 42] or Sint Lumbi [Luke 12, 35] or Nemo accendit [Luke 11, 33]" (Toker, 2009, passim). As already shown, the reading of Luke's gospel is the same as determined by the Dominican liturgy for the feast of Saint Francis of Assisi. Besides that, according to the heading "On the variety of feasts" in the Ritus, Saint Francis' feast is characterized as popular, occupying the third place in the hierarchy, preceded by the most solemn and main feasts, and succeeded by the private ones (Toker, 2009, p. 251-252). 
Considering all this information, it should be noted that Giordano once again ignored the liturgical practices in choosing the verse Venit in civitatem suam that Sunday afternoon, just as he had already done in the morning. In doing so, the preacher once again created the opportunity to address the properties that made the City of God the city par excellence, a mirror for all terrestrial communities, including Florence: "[...] properly speaking, that is the city, the true city [...] blessed are those who will be its citizen. These cities of the world are not worthy of being called cities [...] but we say so because we cannot speak otherwise. This name comes from above, that is the city" (Giordano da Pisa, 1831, p. 87-88).

\section{Preached friar Giordano on 8 OCtOber 1304, THURSDAY MORNING, SAINT Liperata's DAY, TO THE EPISCOPATE IN THE SQUARE}

In the sermon preached on the feast day of the city's patroness saint, Giordano's purpose was to offer the reasons why the saints are the lords of both the earthly and the heavenly cities. Regarding the chosen verse, it should be noted that Matthew 9, 1 - which speaks of Jesus' return to one of his hometowns - was perfectly suited to explore the urban and civic theme as on that day the feast of Florence's patroness saint was celebrated. According to Delcorno, "he opportunely chooses as the subject of the discourse the verse Venit in civitatem suam" (Delcorno, 1975, p. 121). Thus, to adopt the liturgicalevangelical reading of the previous Sunday and to speak about city since the beginning of the week seems to have been considered by Giordano as the most appropriate procedure: firstly, because the thema was propitious to talk about it, which is befitting with the civic feast; second, because to address this since Sunday would already introduce the public to the subject that would invariably be dealt with on Thursday. The Sunday's and Thursday's audiences certainly did not match (the weekday feast was civic, while Saint Francis' feast might have had a narrower appeal), however, it is reasonable to suppose that the public that attended his preaching faithfully and that wrote it down was also present in the preaching of Saint Reparata's day.

Such procedure would be justified, beyond Giordano's personal desire to speak about the quintessential human community that is the city, precisely by the civic value of this celebration. According to the American historian Augustine Thompson, the northern-central Italian communes of the thir- 
teenth- and early fourteenth-centuries were simultaneously civil, religious, and political institutions, so that their government was understood and made through religious rhetoric and rituals (Thompson, 2005, p. 3-6). Thompson states that "lay governments themselves magnified their 'sacred' aspects, associating their cities with patron saints and, especially in the age of the Popolo ${ }^{8}$, adopting wholesale religious language, rituals, and forms" (Thompson, 2005, p. 6). Transcending this observation to a broader field than politics itself, it should be noted that virtually the entire communal population - laymen and clergy, men and women - engaged in such acts (Thompson, 2005, passim) and "through participation in public rituals, individuals created families, families created neighborhoods, and neighborhoods created the city" (Thompson, 2005, p. 141). Through these rituals, the bond established between cities and saints was of reciprocity: the community offered them celebration through public acts of devotion on Earth, while they interceded with God to confer some kind of advantage - usually in the form of protection and/or greater grace and authority (Thompson, 2005, passim). In this sermon in honour of Saint Reparata, Giordano stated: "[...] the saints are made lords of the cities so that we may turn to them in our needs, and to follow them" (Giordano da Pisa, 1831, p. 100).

The oldest cults in the Italian communes usually centred on the cathedral holder(s). The cities celebrated their patrons through public religious rituals, acts of honour that were attended not only by clergy and laymen groups of religious observance, but virtually by the entire city population. The cathedral was the city's home, and it was considered to belong to both the bishop and the population: the commune, in addition to devoting charity donations to it, was also concerned with its physical preservation. This simultaneous possession was physically expressed in the cathedral's square, which was generally the same as that of the commune, as in the Florentine case: in 1296, the guild responsible for the construction of the new cathedral requested the Florentine government to expand the square between the church and the baptistery, creating a bigger one for a greater cathedral (Dean, 2000, p. 34-35; Thompson, 2005, p. 18-21). All of this fostered civic pride as the patron saint(s) was/were considered to protect and impersonate the city, being invoked in official documents of the communal government to perform protective and legitimizing functions. In this latter sense, when the communes disengaged from imperial power in the twelfth century, they began to suffer from a lack of dignity and ancient roots that linked them to the past and thus provided them with the desired civil legitimacy. Thus, their religious-based political organiza- 
tions - where the saints played a key role as intercessors in the relationship between man and God - were intended to fill this gap and replace the emperor (Thompson, 2005, p. 114-141).

The city's personification was not necessarily made only by one saint. Shared patronage was widespread. In the case of Florence, in addition to Saint Reparata, God and the Virgin Mary, the 1325 communal statute also invoked the names of saints Peter, Paul, Philip, James, Barnabas, Zenobius and Miniatus - as well as all the saints of God. Specifically regarding Saint Reparata, a virgin martyr who lived in Caesarea in the third century (Tacconi, 2005, p. 60), the city of Florence engendered a cult in her honour that produced miracle accounts and even the composition of a vita - which, according to Thompson, although pious, was totally fictional (Thompson, 2005, p. 113-114) -, besides acquiring a relic in 1335, which as venerated for four years and four months until it was found to be false (Stefani, 1990, p. 241; Villani, 1991, p. 84). According to the Florentine chronicler Giovanni Villani (1276-1348), the reason for adopting Saint Reparata as patroness was due to the victory of the Roman emperor Honorius (384-423), along with Florentine troops, over the Ostrogoth King Radagaiso (?-406) who had besieged the city around 405-406. He was defeated and Florence was freed precisely on the saint's day (Villani, 1991, p. 72).

Even though this story seems to have been largely unknown to the early fourteenth-century Florentine population, ${ }^{9}$ this did not preclude her veneration by the city. The public feast was even accompanied by a palio, a horse racing competition that according to Thompson, as a sign of its political power, had its cost forcibly covered by the towns submitted to the commune of Florence. A little over a decade after Giordano's death, the communal statute of 1325 established that the chief magistrates of the city government should, as regards the saint and other patrons, each offer a candle on their altars on the eve of their feasts. Particularly regarding Saint Reparata, the monetary offerings made on her day all were destined to the construction of the new cathedral (Villani, 1834, p. 106; Thompson, 2005, p. 120, 172, 173). And although it was named Santa Maria del Fiore, as Giovanni Villani stated, "[...] nevertheless, for all people the first name never changed, Santa Reparata” (Villani, 1991, p. 536). According to another fourteenth-century chronicler, Marchionne di Coppo Stefani (1336-1386), while the cathedral had other names, Santa Reparata was the most appropriate one (Stefani, 1990, p. 241).

In addition to what may be inferred from the fact that the saint was still the holder of the cathedral in Giordano's time, at least in popular terms, the 
confirmation of her importance to the city can be traced by an analysis of the remaining liturgical books of the ancient Florentine cathedral. Although they were composed over a century before the time of Giordano's preaching, the Ritus in ecclesia servandi are still useful to understand the importance of Reparata's feast in the early fourteenth century as they only became truly obsolete when Santa Reparata's cathedral was in fact replaced by Santa Maria del Fiore in 1439/40 (Toker, 2009, p. 30). According to the American archaeologist Franklin Toker, this was also the moment when the appeal for a universal uniformity of the liturgy, based on the Roman rite, was made stronger by the invention of new printing techniques. And although in 1310 the bishop Antonio d'Orso enacted certain reforms in the church's constitution in order to standardize the liturgy in the Florentine diocese, which made the book out of date to some extent (Toker, 2009, p. 30-31), such a reform was made after Giordano's preaching in Florence. Thus, it seems reasonable to use the Ritus to access the cathedral liturgy of the first decade of the fourteenth century.

In the Ritus there is a section called "On the variety of feasts" where solemnities are classified according to their importance:

There are the most solemn, main, popular, and private feats, and for their variety there are various modes of reading and singing. The most solemn feasts are: the Nativity of the Lord, the Epiphany, the Resurrection, as well as [the following] Monday and Tuesday, the Ascension, the Pentecost, the Four Feasts of Saint Mary and the Feast of All Saints. The dedication feast of each church and the patron feasts of each church are most solemn in those churches. At these feasts, may the office be celebrated in the most solemn and devoted way and may everything be carefully sung and read. May the altars be incensed every Nocturn. May more candles be lit than usual. For the introit of the Mass, the Kyrie eleison, the Gloria in excelsis deo, the Sanctus sanctus and the Agnus dei, the singer, with a number of competent assessors, remains positioned in the centre of the choir. At these feasts, the Gradual is duly sung, with its verse, by two [singers] installed in the pulpit; the Alleluia and also the Sequence will be solemnly sung by the singer and his companions from the pulpit. (Toker, 2009, p. 251, emphasis added ${ }^{10}$

In speaking of "each church" and "in those churches", the Ritus' prescriptions concerned all the churches of the Florentine diocese. However, specific determinations are made regarding the Baptistery of Saint John the Baptist, the building across the square in front of the cathedral. The preceding heading, called "On the office of the churches' dedication", begins as follows: "The [feast 
of] dedication of the Church of Saint John the Baptist, which takes place on the eight days before the ides of November, is solemnly celebrated as are celebrated all the other feasts of the Lord". Later, after the title, the following inscription was added to the margin: "Consecration of the altar of Saint Reparata on the day of Saint Leonardo. And it was consecrated by Archbishop Andrew" (Toker, 2009, p. 249). If the reconstruction of the cathedral's liturgical calendar is taken, Saint Leonardo's day was precisely the same day as the dedication of the baptistery of Saint John the Baptist, that is, November 6 (Toker, 2009, p. 63). In other words, in that day, in addition to the feast of Saint Leonardo, it should be celebrated both the dedication of the baptistery of Saint John the Baptist and that of the cathedral of Santa Reparata. Thus, specifically regarding the cathedral in the emphasised excerpt of the heading "On the variety of feasts", it should be understood that the dedication feast of the Cathedral of Santa Reparata (November 6) and the saint's own feast (October 8) are most solemn for the ecclesia matrix and thus for the entire Florentine diocese. Therefore, as regards the liturgical rituals of Florence's cathedral, there is no doubt that the feasts of Saint Reparata were considered to be of greatest importance.

In the Mores et consuetudines canonice Florentine (1231), a book dedicated especially to the correct ringing of the belfry's bells according to the rhythm of the worships and the physical maintenance of altars of the cathedral (Toker, 2009, p. 30), regarding Saint Reparata there is the following passage that demonstrates a special care for the rituals of her day:

In the feast of Saint Reparata, let us do for each thing what was previously assigned for the feast of Saint Zenobius, and may especially be ornamented the altars, the lamps, and choir, entirely from top to bottom, and put myrtle and laurel everywhere. From the beginning to the end of the octave [of the feast], do as in the feast of Saint Zenobius. (Toker, 2006, p. 279)

The heading dedicated to Zenobius, also a patron saint of Florence, ${ }^{11}$ begins by describing the ringing of the belfry's bells which, on this occasion, as well as for Reparata's feast, should be sounded by four successions, on the vigil of the eve and on the morning of the feast day, "just as for the most solemn feasts". For these occasions, the following was also prescribed:

The church be completely clean. The lamps are to be washed and ornamented wherever they are in the church, especially under the arches and in the centre of the church aisle. Be the seats for the clerics placed before the archways of the 
church. At the Vespers, the Vigil and the Mass, all the clerics of the city must be present; and every day and night services we celebrate, today and throughout the octave, at his altar. In the morning, after the Mass of the people, all the bells are sound until the preaching of the bishop or another [clergyman], if the bishop is not present. After the preaching, we all gather in the church of Saint John [the baptistery in front of the cathedral], where we recited the Terce. In the meantime, the bishop and his ministers prepare themselves. When all are ready, with the cross and candles in front, behind them [the clerics] are positioned, starting from the last one [in the hierarchy] to the bishop, we leave Saint John's Church and go to the Church of Santa Reparata, where the body of our blessed father Zenobius rests. There we pray the Mass, whose processional chant is the Apostles' hymn Iam non dicam, since he [Zenobius] was our Apostle. Let aer antensis be arranged so that, on the day of the vigil, the church, especially around its altar and in front of the arcades, will be adorned with myrtles and laurels in abundance. Before the octave, we sound two bells at the same time every day. During the octave, ring three sequences of four bells for vespers, vigils, and matins, because for the vesper of the octave it is done as on Sunday. (Toker, 2009, p. 278)

Further on, there is the following inscription:

These are the feasts in which the whole church is to be cleansed and swept away by the servant, that is, to Saint Zenobius, to Saint Reparata, to the Nativity of the Lord, and to the Easter of Resurrection [...] Below are prescribed the feasts at which is to be preached by a canon or commissioner, that is, on the day of Saint Zenobius, on the Nativity of Blessed John the Baptist and also on the day of his decapitation, on the day of Saint Matthew, on the day of Saint Reparata [...] The days in which the bishop is to preach and sing the Mass himself are: Saint Zenobius Day, Pentecost Day, Nativity Day of Blessed John the Baptist, Saint Matthew, Saint Reparata [...]. (Toker, 2009, p. 281, emphasis added)

In the sense of civic and urban exaltation, the Mores also demonstrate the power that the Florentine cathedral wielded over the churches of its diocese in tax terms - both those in the city itself and those found in the countryside. Precisely on the date of the feast of Saint Reparata, this power stands out regarding one of the rural churches. According to the text,

On the day of the feast of Saint Reparata, it is due to the canonicate of Florence, from the people who live of the land in the parish of Saint Andrew in Colle di Val di Pesa, three bushels of salt according to the Florentine measure of a grain bu- 
shel, that I, Father Salvi, chaplain of this canonicate, received from the said canonicate of Gherardino, son of Beneviene of the predicted parish of Saint Andrew, and from Arrigo, the son of Rinaldo dei Castiglione, who leases and works the land for this canonicate. (Toker, 2009, p. 282) 12 $^{12}$

According to Franklin Toker, all the prescriptions regarding the payment of taxes in supplies stipulated by Mores show that, together with Easter, Pentecost and All Saints' Day, Reparata's Day was one of the main dates in this influx from the countryside to the city (Toker, 2009, p. 152). Thus, October 8 may have been an opportunity to assert the city and the commune not only for itself, but also for the towns and parishes of Florentine contado.

Once demonstrated the civic-liturgical importance of Saint Reparata's feast, finally it must also be noted that on this day, again, friar Giordano did not follow the Mass readings specified by the cathedral's liturgy. Under the heading "On the feast of Saint Reparata" the Ritus states the following:

The feast of Saint Reparata, glorious virgin and martyr, whose patronage supports and sublimates our church, reverently and with great devotion we acknowledge and venerate her $[\ldots]$ that her altar be incense [...] For the Matins [...] read the readings of her life and martyrdom. For all the rest of the day and night, follow [the rite] proper for a virgin (Toker, 2009, p. 247).

The heading dedicated to a virgin reads as follows: "In the office of the Mass [...] the Epistle is Qui gloriatur [I Corinthians 1, 31] or Confitebor [Romans 15, 9] or [the antiphon] Domine deus exaltasti; the Gospel is Simile est regnum celorum decem virginibus [Matthew 25, 1] or Simile est regum celorum thesaurus [Matthew 13, 44]" (Toker, 2009, p. 222). Giordano, therefore, once again ignored the liturgy in choosing the thema of his preaching, demonstrating a persistent fondness for the passage of Matthew 9, 1. As stated, by featuring the word civitas this verse enabled the preacher to discuss how the saints are lords of all cities, the earthly ones (especially of those that adopt them as patrons) and the heavenly one; and to point out that Saint Reparata, as well as an earthly podestà, was Florence's ruler:

[...] Florence is especially Saint Reparata’s [...] about Saint Reparata, her third city [besides the other earthly ones and the heavenly city] is this city of Florence [...] When a person has a city to govern he is said lord, as are the podestà. And they are not lords for any other reason than that they are said to be lords by their government. In this way the saints are lords of the cities. And Saint Reparata is 
[the mistress] of this [city], since she is its chief, ruler, and special guardian. (Giordano da Pisa, 1831, p. 89-98)

\section{Conclusion}

By preferring the verse of Matthew 9, 1 as thema of all of these three preachings of October, 1304, Giordano consciously ignored the liturgical customs of sermon composition (which he knew very well) on all occasions something quite exceptional in all his activities as a preacher. Based on the analysis of the evidence associated with these pronouncements, it is reasonable to say that the friar did so because of the proven civic-liturgical importance of the feast of Saint Reparata, patroness of Florence, celebrated on October 8. Thus, for Giordano, already on Sunday, to introduce the city theme raised by the upcoming celebration would be imperative to the point that the preacher would not abide to any liturgical determination (of his own Order or of the Florentine church) and justify his choice of the verse Venit in civitatem as thema for all Sunday preachings (both that done at Santa Maria Novella and the one at the cathedral), as well as that of Thursday.

Given the civic and liturgical importance of the patroness' feast day, for she personified Florence, Giordano seems to have considered appropriate to discuss the city and its characteristics; how men should live in it; to speak of the bond that the saints have with it; and the correspondences between the earthly and heavenly cities. By selecting a verse in which the word civitas figures, the preacher himself created the opportunity to discuss it. That means that Giordano wished to speak about city and that, conveniently because of its first verse, the pericope of the Nineteenth Sunday after Trinity Sunday offered him the perfect or the most appropriate opportunity for it. All this, therefore, reinforces the close connection that could occasionally exist between sermon/preaching and political life in the late thirteenth- and early fourteenth-century Italian communes - even in an everyday preaching such as Giordano's - as well as the preacher's appreciation for themes connected to city life. 


\section{BIBLIOGRAPHIC REFERENCES}

ALVES, Aléssio Alonso. Sermons, Preaching, and Liturgy: Practices, Research Methods, and the Case of Giordano da Pisa. Medieval Sermon Studies, London: Taylor and Francis Group, v. 62, n. 1, p. 3-16, 2018.

BATAILLON, Louis-Jean. Approaches to the Study of Medieval Sermons. Leeds Studies in English, n. 11, p. 19-35, 1980.

BONNIWELL, William. A History of the Dominican Liturgy (1215-1945). New York: Joseph F. Wagner, 1945.

CORBARI, Eliana. Vernacular Theology: Dominican Sermons and Audience in Late Medieval Italy. Tese (Doutorado em Filosofia) - Faculdade de Artes, Universidade de Bristol, Bristol, 2008.

DAMERON, George W. Florence and Its Church in the Age of Dante. Philadelphya: University of Pennsylvania Press, 2005.

DEAN, Trevor. The Towns of Italy in the Later Middles Ages. Manchester: Manchester University Press, 2000.

DELCORNO, Carlo. Giordano da Pisa e l'antica predicazione volgare. Firenze: Leo S. Olschki Editore, 1975.

DELCORNO, Carlo. Giordano da Pisa. In: DELCORNO, Carlo. Dizionario biografico degli italiani. Roma: Istituto della Enciclopedia italiana, 2001. Disponível em: https://bityli.com/5pNnX. Acesso em: 30 set. 2019.

PISA, Giordano Da. Prediche del beato fra Giordano da Rivalto dell'Ordine dei Predicatori recitate in Firenze dal MCCIII al MCCCVI ed ora per la prima volta publicate. Tomo II. Firenze: Magheri, 1831.

HUB, Bertold. Vedete come è bella la cittade quando è ordinata: Politics and the Art of City Planning in Republican Siena. In: STEINHOF, Judith; SMITH, Timothy. Art as Politics in Medieval and Early Renaissance Siena. Farnham: Ashgate, 2012. p. 61-82.

IANNELLA, Cecilia. Giordano da Pisa: Ética Urbana e Forme della Società. Pisa: Edizione Ets, 1999.

FUSIGNANO, Jacobus de. Libellus Artis Predicatorie. In: WENZEL, Siegfried. The Art of Preaching: Five Medieval Texts \& Translations. Washington, D.C.: The Catholic University of America Press, 2013. p. 9-96.

VORAGINE, Jacques de. Sermones dominicales per totum annum. Venetiis: ex officina Ioannis Baptistae Somaschi, 1572.

VORAGINE, Jacques de. Sermones de sanctis per anni totius circulum. Venetiis: ex officina Ioannis Baptistae Somaschi, 1573.

MEIER, Ulrick. Mensch und Bürger: die Stadt im Denken spätmittelalterlicher Theologen, Philosophen und Juristen. München: Oldenbourg Verlag, 1994. 
MEIER, Ulrich. Urbane Utopien: Die mittelalterliche Stadt in Dominikanerpredigten. In: SCHILP, Thomas; WELZEL, Barbara. Die Dortmunder Dominikaner und die Propsteikirche als Erinnerungsort. Bielefeld: Verlag für Regionalgeschichte, 2006. p. 11-34.

MIATELLO, André Luis Pereira Miatello. Giordano de Pisa (1260-1311) e os três significados da cidade: um ensaio de política urbana medieval. Revista Tempo, v. 23, n. 2, p. 239-263, 2017.

ORDO PRAEDICATORUM. Missale ordinis praedicatorum. Venedig: Nikolaus von Frankfurt, 1484.

ORDO PRAEDICATORUM. Missale s[ecundu] $m$ consuetudinem fratrum predicatorum. Venedig: Andreas Torresanus, 1496.

ORDO PRAEDICATORUM. Ordinarium Juxta Ritum Sacri Ordinis Fratrum Praedicatorum. Romae: Apud Collegium Angelicum, 1921.

STEFANI, Marchionne de Coppo. Cronica Fiorentina. In: MURATORI, L. A. Rerum italicarum scriptores: raccolta degli storici italiani dal cinquecento al millecinquecento. Città di Castello: S. Lapi, 1900.

TACCONI, Marica. Cathedral and Civic Ritual in Late Medieval and Renaissance Florence: The Service Books of Santa Maria del Fiore. Cambridge: Cambridge University Press, 2005.

TOKER, Franklin. On Holy Ground. Liturgy, Architecture, and Urbanism in the Cathedral and the Streets of Medieval Florence. Turnhout: Harvey Miller Publishers, 2009.

WALEYS, Thomae. De modo componendi sermones cum documentis. In: CHARLAND, Thomas-Marie. Artes Predicandi: Contribution a l'Histoire de la Rhétorique au Moyen Age. Ottawa: Insti. D’Études Médiévales, 1936. p. 325-403.

THOMPSON, Augustine. Cities of God: The Religion of the Italian Communes. University Park: The Pennsylvania State University Press, 2005.

URFELS-CAPOT, Anne-Élisabeth. Le Sanctoral de l'Office Dominicain (1254-1256). Paris: Écoles de Chartes, 2007.

VILLANI, Giovanni. Nuova cronica. Parma: Fondazione Pietro Bembo: Guanda, 1991. VILLANI, Matteo; VILLANI, Filippo; COMPAGNHI, Dino. Cronica Di Matteo e Filippo Villani con Le Vite D'Uomini Illustri Fiorentini di Filippo e la Cronica di Dino Compagni. Milano: Per Nicolò Bettoni e Comp., 1834.

WENZEL, Siegfried. Medieval Ars Praedicand: a Synthesis of Scholastic Sermon Structure. Toronto: University of Toronto Press, 2015. 
Preaching, the city, and the saints: an analysis of the civic-liturgical context

\section{NOTES}

${ }^{1}$ Besides the recording of the preaching that states the presence of all city clergy, including the bishop, those is information are reinforced by the cathedral's liturgical customs according to the liturgical book entitled Mores et consuetudines canonice Florentine (Toker, 2009, p. 157-264).

${ }^{2}$ The construction of the new cathedral, Santa Maria del Fiore, initiated in 1296 when its walls began to be erected and the demolition of Santa Reparata started, which was completed only in 1375. That year, however, the new cathedral was not yet ready: it was finished in $1439 / 40$.

${ }^{3}$ In Florence, Giordano was lector sententiarium between 1302 and 1304 (lecturing on Peter Lombard's Sententiae), and lector principalis from 1304 to 1307 (lecturing on the Bible). The Preacher General office, granted to Giordano in 1303, was the highest among those which, within the Order, had preaching as their main occupation. It allowed a friar to preach anywhere in his province.

${ }^{4}$ A biblical passage usually taken from the liturgical-evangelical reading of the day, from which the sermon was developed. See Alves, 2019, p. 4; Bataillon, 1908, p. 28-29; Delcorno, 1975, p. 115-116; Wenzel, 2015, p. XV.

${ }^{5}$ The Ordinarium is a liturgical book that briefly presents the hymns and the readings for Masses and offices throughout the year, all of which appear entirely in the Missale.

${ }^{6}$ Designation found in the liturgical calendar of the Order presented by William Bonniwell and in the edition of the lectionarium de santis by Anne-Élisabeth Urfels-Capot (Bonniwell, 1945, p. 109; Urfels-Capot, 2007, p. 384). However, in the missals of 1484 and 1496, the feast appears as duplex (Ordo Praedicatorum, 1484, p. X; 1496, p. XII). The pagination of the missals in Roman numerals was designated by myself. The pages leading up to their beginning and containing the liturgical calendar have no numbering. This was made considering as page I the first one that has some inscription on the adverse side of the sheet.

${ }^{7}$ In order of increasing importance, the feasts are classified as: trium lectionum, simplex, semiduplex, duplex and totum duplex (Urfels-Capot, 2007, p. 28-29, 801).

${ }^{8} \mathrm{Mid}$ and second half of the thirteenth century.

${ }^{9}$ According to chronicler Matteo Villani (1283-1363) - who after the death of his brother Giovanni in 1348 continued his chronicle - around 1353 "the priors [of the Craft Corporations in charge of the city government] wanted to clarify why the cathedral church of Florence was called Santa Reparata and why, by ancient custom, on that day a palio took palace in Florence" (Villani, 1834, p. 106). Although Giovanni had already attested the reason (then repeated by his brother), the story, by Matteo's account, seems not to have been generally known in the mid-fourteenth century - which suggests that it was neither in 1304 . Her worship, however, can be dated back to the sixth century (Dameron, 2005, p. 201).

10 'Nocturn' is the celebration of the Divine Office called 'Matins' or 'Vigils', which is prayed at night or at dawn. It is composed of two or three parts, depending on the feast, each called 
'Nocturn', during which three psalms are sung and three readings are made. 'Gradual' is the 'Mass' part between the reading of the epistle and the gospel; it is sung in a responsorial way: there is a chorus (sung by the choir) and verse (sung by the singers). 'Sequence' is a melodic hymn whose lyrics emphasize the celebrated feast, and may contain a saint's life in rhyme and music.

${ }^{11}$ According to Giovanni Villani, Zenobius was a Florentine, bishop of the city at the time of the Ostrogoth siege when Reparata was adopted as patroness in the early fifth century. According to him, "[...] it is believed that by his merits our city was released from the Goths [...]" (Villani, 1991, p. 72). Therefore, he is also a saint of evident civic value, whose feast is celebrated on May 25. As for Reparata, it is important to note that she, a foreign woman, in liturgical terms occupied the same position of saintly importance as a native bishop.

12 The parish of Saint Andrew in the village of Colle di Val di Pesa (now the commune of San Casciano Val di Pesa) was located southwest of Florence, between the Pesa and Greve rivers (Toker, 2009, p. 152-153).

Artigo recebido em 4 de outubro de 2019.

Aprovado em 3 de março de 2020. 